\title{
EVOLUCIÓN DE LOS PRECIOS DE VIVIENDA Y DE SUELO URBANO EN ESPANAA / EVOLUTION IN PRICES OF HOUSING AND URBAN SOIL IN SPAIN
}

María Gómez Riocerezo ${ }^{1}$

Ministerio de Fomento

\section{Resumen}

En este trabajo se analiza la evolución que han experimentado los precios de la vivienda y del suelo urbano a partir de los datos aportados por las estadísticas disponibles en la Subdirección General de Estudios Económicos y Estadísticas del Ministerio de Fomento. El período temporal considerado comprende desde el año 2004 hasta el primer trimestre de 2012, corroborando el ajuste del que han sido objeto dichos precios desde finales de 2007.

Palabras clave: Vivienda; Suelo urbano; Precios; España.

\section{Abstract}

In this paper evolution in prices of housing and urban soil is analysed by using the data included in the statistics available in the Subdirección General de Estudios Económicos y Estadísticas (Department of Economic Studies and Statistics) belonging to the Ministerio de Fomento (Ministry of Public Works). The study period goes from 2004 to the first quarter of 2012, in order to confirm the adjustment these prices have suffered from the end of 2007.

Keywords: Housing; Urban soil; Prices; Spain.

\section{INTRODUCCIÓN}

Durante el período 1997-2007 han tenido lugar intensas subidas de los precios de la vivienda en la mayor parte de los países

\section{INTRODUCTION}

Between 1997 and 2007, most developed countries have seen a considerable increase in housing prices,

\footnotetext{
${ }^{1}$ Jefe de Área. Subdirección General de Estudios Económicos y Estadísticas. Ministerio de Fomento.
} 
desarrollados, coincidiendo con los tipos de interés más bajos de los últimos cincuenta años y con unas mejorías sensibles en las restantes condiciones de financiación (plazo, relación préstamo/ valor). Los precios inmobiliarios más altos han impulsado un crecimiento mayor de las economías más afectadas por dicho proceso, apoyado en el mayor gasto en vivienda y en consumo familiar. El crecimiento citado ha estado acompañado, además, por un fuerte aumento de los niveles de endeudamiento familiar, por lo que la evolución incrementista de los precios de la vivienda ha contribuido a aumentar, en general, el problema de acceso a la misma por parte de los ciudadanos.

España es uno de los países con un acusado crecimiento de los precios de la vivienda. El principal elemento diferencial de España con los restantes países desarrollados en este proceso ha sido la particular intensidad que ha supuesto, hasta fechas bien recientes, el volumen de nueva construcción que en la actualidad, y por razones de todos conocidas, ha sufrido un notable cambio de tendencia.

El ajuste del sector de la vivienda, iniciado en 2007, se precipitó de manera brusca en 2008, como consecuencia, por una parte, de la crisis financiera mundial, y por otra, de factores internos como son: el deterioro de la economía española, la falta de financiación y el agotamiento del modelo de crecimiento basado en la construcción. A principios del año 2010, la información disponible muestra que el mercado de la vivienda ha entrado en una fase de mayor estabilidad.

La Subdirección de Estudios Económicos y Estadísticas del Ministerio de Fomento elabora, entre otras, las Estadísticas de Precios de Vivienda y de Precios de Suelo. Con la información obtenida en dichas a period when interest rates have been the lowest in the last 50 years and a time when important improvements in other financing conditions (term, relationship loan/price) have also taken place. Higher prices of real estates have fostered a greater growth in the economies more affected by this process, as a result of a higher expenditure in housing purchase and domestic economy. This growth has also meant a considerable increase in households in debt, so the incremental evolution in housing prices has contributed to amplify the problem of people to purchase a dwelling.

Spain is one of the countries which has observed a huge increase in housing prices. The main difference between Spain and the rest of developed countries has been the special focus on new buildings in the process, which nowadays and due to well-known reasons has suffered a considerable change in its trend.

The adjustment in the housing industry, which began in 2007, took place sharply in 2008; on the one hand, as a result of the worldwide financial crisis, and, on the other hand, due to internal factors, such as the deterioration of the Spanish economy, the lack of financing and the end of a growth model based on building. From the beginning of 2010 onwards, the available information shows that the housing market has entered a greater stability stage.

The Subdirección de Estudios Económicos y Estadísticas (Department of Economic Studies and Statistics) belonging to the Ministerio de Fomento (Ministry of Public Works) prepares, among others, the Statistics of Housing and Soil Prices. The data included in those statistics will allow us to check how the prices in housing 
estadísticas podremos comprobar, a continuación, cómo han evolucionando el sector de la vivienda y el sector del suelo desde el año 2004.

Con el fin de conseguir nuestro cometido procederemos, en primer término a exponer brevemente la metodología que utilizan dichas estadísticas, para elaborar los precios de vivienda y de suelo.

\section{ESTADÍSTICA DE PRECIOS DE VIVIENDA}

La Estadística de Precios de Vivienda tiene como principal objetivo estimar el precio de la vivienda del mercado inmobiliario en España tanto a nivel provincial como regional, lo que nos permitirá conocer su evolución trimestral y anual.

Para dicha estimación, clasificamos la vivienda en función de su acceso al mercado inmobiliario en vivienda libre y vivienda protegida. Se utiliza otro criterio diferenciador como es que la vivienda sea nueva o de segunda mano.

A tal efecto se considera vivienda libre si la vivienda accede libremente al mercado inmobiliario y vivienda protegida si existen restricciones legales sobre precios, superficies y otras cuestiones referentes al mercado hipotecario, señaladas por ley. En cuanto a la vivienda nueva o de segunda mano, será el año de construcción de la vivienda el que posibilite tal clasificación.

\subsection{Recogida de la información}

La información se recoge por la Asociación Profesional de Sociedades de Valoración (ATASA), entidad sin fines de lucro que agrupa a las empresas de este sector. ATASA coordina la recogida de la and urban soil sectors have evolved since 2004.

In order to reach our aim, firstly, we will briefly describe the methodology those statistics apply in order to determine the prices of housing and soil.

\section{STATISTICS OF HOUSING PRICES}

The aim of this Statistics is to estimate the price of housing in the Spanish real estate market, both at a provincial and regional level, which will allow us to know the quarterly and annual evolution.

To obtain that estimation, housing is divided into free-market housing and state-subsidized housing, according to the way of access to the real estate market.

In that sense, free-market housing is considered to be the housing which enters the real estate market in a free way, whereas the housing is considered to be state-subsidized when there are some legal restrictions regarding prices, areas and other issues related to the real estate market. With regard to new and secondhand housing, the criterion used for the different group is the building year.

\subsection{Data collection}

Information is collected by the Asociación Profesional de Sociedades de Valoración (ATASA) (Professional Association of Property Appraisal Companies), which is a non-profit institution. This association coordinates the collection of information and provides the data included in the databases prepared by the property appraisal companies to the responsible 
información y facilita los datos procedentes de las bases de datos de las empresas de valoración de inmuebles a la unidad promotora de la Estadística de Precios de Vivienda en soporte magnético, con un diseño de registro preestablecido y en los plazos acordados. Antes de la remisión de la información, ATASA realiza un trabajo previo de consistencia y validación de datos.

Una vez disponible la información en soporte magnético, se lleva a cabo un análisis exhaustivo de los datos, con el fin de detectar y depurar errores. Se utilizan diferentes técnicas de imputación dependiendo de cada tipo de error.

- La unidad de análisis es la vivienda. A tal efecto, se excluyen las viviendas que en el período de referencia estén en fase de construcción o cuyo uso no sea propio para la residencia de un hogar.

- La población objeto de estudio está formada por todas las viviendas que han sido valoradas por las empresas de tasación en un determinado trimestre. La población es variable trimestralmente, puesto que depende del número de valoraciones efectuadas por las empresas de tasación.

- El ámbito geográfico comprende todo el territorio nacional, incluidas las Ciudades Autónomas de Ceuta y Melilla.

- Esta estadística se lleva a cabo con carácter trimestral.

\section{Variables}

Los registros que corresponden a cada una de las tasaciones realizadas, tienen la misma estructura y están compuestos por las siguientes variables:

- Tipo de transacción

- Provincia

- Código provincial

- Municipio unit of the Statistics of Housing Prices, in a magnetic device, with a predetermined registration design and in the agreed deadlines. Before sending the information, ATASA association carries out a previous activity of data consistency and validation.

Once the information is available in a magnetic device, an exhaustive analysis of data is developed, in order to detect and mend mistakes. Different methods are used, depending on the type of mistake.

- The analysis unit is the housing. In this sense, both housing in a building phase in the reference period and housing whose use is not for a dwelling are excluded.

- The study population is the housing that has been evaluated by the property appraisal companies in a certain quarter. The population is different each quarter since it depends on the number of property appraisals developed by the companies.

- The geographical area is the whole country, including Ceuta and Melilla.

- The statistics is quarterly developed.

\section{Variables}

The entries corresponding to each one of the property appraisals have the same structure and are composed of the following variables:

- Type of transaction

- Province

- Province code

- Municipality 
- Código municipal

- Código postal

- Fecha de tasación

- Valor de tasación

- Superficie construida

- Año de antigüedad de la vivienda

La variable 'tipo de transacción' especifica la tipología de la vivienda. Existen, como ya hemos avanzado, dos tipos de viviendas perfectamente diferenciadas, viviendas libres y viviendas protegidas.

Los códigos provincial y municipal, de acuerdo con la codificación del Instituto Nacional de Estadística, permiten localizar geográficamente la observación dentro del territorio nacional, es decir, su asignación a una Comunidad Autónoma, provincia y municipio. El código postal permitirá profundizar los estudios en pequeñas áreas.

La 'fecha de tasación' especifica el momento de realización de la tasación y determina si la observación está fuera o no del período de referencia establecido.

El 'valor de tasación' es el valor que la empresa tasadora calcula para cada una de las viviendas.

La 'superficie construida' nos indica los metros cuadrados construidos que tiene la vivienda.

La variable 'año de antigüedad' clasifica a las viviendas como de nueva construcción o de segunda mano. En la estadística se definen como viviendas de nueva construcción aquellas que tienen entre 0 y 1 año de antigüedad, mientras que el resto se clasifican como de segunda mano.
- Municipality code

- Postal code

- Date of appraisal

- Value of appraisal

- Built area

- Housing age

The variable 'type of transaction' indicates the type of housing. As it has been said above, there are two different types of housing: free-market and statesubsidized housing.

The province and municipality codes, according to the Spanish Statistics Institute classification, allow us to geographically locate the unit in the Spanish area, that is, its allocation to a region, province and municipality. The postal code will allow us to study smaller areas in depth.

The 'date of property appraisal' indicates the moment when the appraisal is made and allows us to determine whether the observation is included or not in the reference period.

The 'value of property appraisal' is the value that the property appraisal firm calculates for the housing.

The 'built area' is the measure of square metres built in the housing.

The variable 'housing age' allows us to divide housing into new or second-hand. New building housing is defined in the statistics as housing which is between zero and one year old, whereas the rest is grouped under second-hand housing. 


\subsection{Estimación de precios}

La variable 'tipo de transacción' permite un análisis independiente para cada tipo de vivienda, vivienda libre y vivienda protegida. Esta variable clasifica inequívocamente a las viviendas en uno u otro tipo, generando al mismo tiempo, dos bases de datos. El tratamiento dado a cada base de datos es idéntico y se explica a continuación.

\subsubsection{Estimación de precios de vivienda libre}

Para cada tipo de vivienda $j$ (nueva construcción o de segunda mano) en el estrato $k$ de la zona geográfica $z$ en el período $t$, se define la variable bidimensional $(X, Y)$ donde $X$ representa el valor de mercado de la vivienda en euros, e $Y$ representa la superficie construida expresada en metros cuadrados.

El precio por metro cuadrado de las viviendas de tipo $j$ en el estrato $k$ de la zona geográfica $z$ en el período $t$ vendrá definido por el siguiente cociente:

$$
P_{j k z}^{t}=\sum_{i} X_{i j k z}^{t} / n_{j k z}^{t} / \sum_{i} Y_{i j k z}^{t} / n_{j k z}^{t}
$$

cuya expresión simplificada es:

$$
P_{j k z}^{t}=\sum_{i} X_{i j k z}^{t} / \sum_{i} Y_{i j k z}^{t}
$$

siendo:

$P_{j k z}^{t} \quad$ el precio por metro cuadrado (euros $/ \mathrm{m}^{2}$ ) de las viviendas de tipo $j$ en el estrato $k$ de la zona geográfica $z$ y en el período $t$,

$\sum_{i} X_{i j k z}^{t} / n_{j k z}^{t} \quad$ el valor medio de las viviendas de tipo $j$ en el estrato $k$ de la zona geográfica $z$ y en el período $t$,

\subsection{Price estimation}

The variable 'type of transaction' allows for an independent analysis for each type of housing: free-market and statesubsidized. This variable unequivocally groups housing into one of both types, which at the same time leads to two different databases. The processing of each database is identical and described below.

\subsubsection{Free-market housing price estimation}

For each type of housing $j$ (new building or second-hand one) in the stratum $k$ belonging to the geographical area $z$ in the period $t$, a two-dimensional variable $(X, Y)$ is defined, where $X$ indicates the housing market value (in Euros) and $Y$ indicates the built area measured in square metres.

The price for housing $j$ in the stratum $k$ belonging to the geographical area $z$ in the period $t$ is expressed by the following formulae:

$$
P_{j k z}^{t}=\sum_{i} X_{i j k z}^{t} / n_{j k z}^{t} / \sum_{i} Y_{i j k z}^{t} / n_{j k z}^{t}
$$

whose simplified expression is:

$$
P_{j k z}^{t}=\sum_{i} X_{i j k z}^{t} / \sum_{i} Y_{i j k z}^{t}
$$

where:

$P_{j k z}^{t} \quad$ is the price per square metre (Euros $/ \mathrm{m}^{2}$ ) of housing $j$ in the stratum $k$ belonging to the geographical area $z$ and in the period $t$,

$\sum_{i} X_{i j k z}^{t} / n_{j k z}^{t} \quad$ is the mean value of housing $j$ in the stratum $k$ belonging to the geographical area $\mathrm{z}$ and in the period $t$, 
$\sum_{i} Y_{i j k z}^{t} / n_{j k z}^{t}$ la superficie media de las viviendas de tipo $j$ en el estrato $k$ de la zona geográfica $z$ y en el período $t$.

El precio por metro cuadrado de la vivienda tipo $j$ en la zona $z$ en el período $t$ se obtiene como media aritmética ponderada de los precios por metro cuadrado en cada uno de los estratos $k$ de las viviendas de tipo $j$ en la zona geográfica $z$ y en el período $t$ :

$$
P_{j z}^{t}=\sum_{k} \alpha_{j k z}^{t} P_{j k z}^{t}
$$

La ponderación $\alpha_{j k z}^{t}$ representa el número de viviendas de tipo $j$ del estrato $k$ de la zona geográfica $z$ en el período $t$ sobre el número total de viviendas de tipo $j$ de la zona geográfica $z$ en el período $t$ :

$$
\alpha_{j k z}^{t}=n_{j k z}^{t} / \sum_{k} n_{j k z}^{t}
$$

Donde:

$n_{j k z}^{t} \quad$ es el número de viviendas de tipo $j$ del estrato $k$ en la zona geográfica $z$ en el período $t$,

$\sum_{k} n_{j k z}^{t} \quad$ es el número total de viviendas de tipo $j$ en la zona $z$ en el período $t$.

La suma de los coeficientes de ponderación es la unidad:

$$
\sum_{k} \alpha_{j k z}^{t}=1
$$

El precio de vivienda libre por metro cuadrado se define como media aritmética ponderada de los precios de cada tipo de vivienda por metro cuadrado:

$$
P_{z}^{t}=\sum_{j} q_{j z}^{t} P_{j z}^{t}
$$

$\sum_{i} Y_{i j k z}^{t} / n_{j k z}^{t}$ is the mean area of housing $j$ in the stratum $k$ belonging to the geographical area $z$ and in the period $t$.

The square metre price of housing $j$ in the geographical area $z$ in the period $t$ is a weighted arithmetic mean of prices in each one of the strata $k$ of housing $j$ in the geographical area $z$ and in the period $t$ :

$$
P_{j z}^{t}=\sum_{k} \alpha_{j k z}^{t} P_{j k z}^{t}
$$

The weight coefficient $\alpha_{j k z}^{t}$ indicates the number of housing $j$ in the stratum $k$ belonging to the geographical area $z$ in the period $t$ :

$$
\alpha_{j k z}^{t}=n_{j k z}^{t} / \sum_{k} n_{j k z}^{t}
$$

where:

$n_{j k z}^{t} \quad$ is the number of housing $j$ in the stratum $k$ belonging to the geographical area $z$ in the period $t$,

$\sum_{k} n_{j k z}^{t}$ is the total number of housing $j$ in the geographical area $z$ in the period $t$.

The addition of the weight coefficients equals one:

$$
\sum_{k} \alpha_{j k z}^{t}=1
$$

The square metre price for free-market housing is defined as the arithmetic mean of square metre prices for each type of housing:

$$
P_{z}^{t}=\sum_{j} q_{j z}^{t} P_{j z}^{t}
$$


Las ponderaciones vienen definidas por el número de viviendas de tipo $j$ en la zona geográfica $z$ en el período $t$ sobre el número total de viviendas en la zona geográfica $z$ en el período $t$ :

$$
q_{j z}^{t}=n_{j z}^{t} / \sum_{j} n_{j z}^{t}
$$

Donde:

$n_{j z}^{t} \quad$ es el número de viviendas de tipo $j$ en la zona geográfica $z$ en el período $t$,

$\sum_{j} n_{j z}^{t}$ es el número total de viviendas en la zona geográfica $z$ en el período $t$.

La suma de los coeficientes de ponderación es la unidad:

$$
\sum_{j} q_{j z}^{t}=1
$$

\subsubsection{Estimaciones de precios de vivienda protegida}

Las consideraciones establecidas para la estimación del precio de la vivienda libre pueden realizarse en la estimación del precio de la vivienda protegida. La única salvedad a considerar es que los valores de la vivienda protegida vienen determinados por el valor máximo legal.

\section{ESTADÍSTICA DE PRECIOS DE SUELO}

La Estadística de Precios de Suelo tiene como principal objetivo estimar el precio del suelo urbano y urbanizable en España a nivel provincial y regional y conocer su evolución trimestral y anual.
The weight coefficients are defined as the quotient between the number of housing $j$ in the geographical area $z$ in the period $t$ and the total number of housing in the geographical area $\mathrm{z}$ in the period $t$ :

$$
q_{j z}^{t}=n_{j z}^{t} / \sum_{j} n_{j z}^{t}
$$

where:

$n_{j z}^{t} \quad$ is the number of housing $j$ in the geographical area $z$ in the period $t$,

$\sum_{j} n_{j z}^{t}$ is the total number of housing in the geographical area $\mathrm{z}$ in the period $t$.

The addition of the weight coefficients equals one:

$$
\sum_{j} q_{j z}^{t}=1
$$

\subsubsection{State-subsidized housing price estimation}

All the considerations made for the estimation of price of free-market housing can also be applied to the estimation of price corresponding to state-subsidized housing. The only difference is that there is a maximum legal price for this type of housing.

\section{STATISTICS OF SOIL PRICES}

The main aim of the Statistics of Soil Prices is to estimate the price of urban soil and building land in Spain both at a provincial and regional level, as well as to analyse its quarterly and annual evolution. 
Además facilita el número, el valor y la superficie de las transacciones registradas en un determinado trimestre.

\subsection{Recogida de la información}

Los datos para la elaboración de esta estadística se reciben del Colegio de Registradores de la Propiedad y Mercantiles de España. El Colegio de Registradores, entidad sin fines de lucro, agrupa a todos los registradores que ejercen su actividad dentro del territorio español.

Esta Entidad coordina la recogida de la información procedente de las bases de datos de los Registros de la Propiedad y facilita datos trimestrales y anuales a la unidad promotora de la Estadística de Precios de Suelo del Ministerio de Fomento, en soporte magnético con un diseño de registro acordado, en función de los objetivos de la estadística y en plazos preestablecidos. Antes de la remisión de la información el Colegio de Registradores realiza un trabajo previo de consistencia y validación de la información.

Una vez recibida la información por el servicio promotor, se lleva a cabo un análisis exhaustivo de los datos, con el fin de detectar y depurar errores. Se utilizan diferentes técnicas de imputación dependiendo de cada tipo de error.

- La unidad de análisis es el terreno de suelo urbano o urbanizable.

- La población objeto de estudio está constituida por todos aquellos terrenos inscritos como urbanos y urbanizables que han sido objeto de transacción en un determinado trimestre. La población de estudio es variable ya que depende del número de transacciones realizadas en el período de tiempo considerado.
Moreover, it provides the number, value and area corresponding to the recorded transactions in a certain quarter.

\subsection{Data collection}

Data for the preparation of this statistics are provided by the Colegio de Registradores de la Propiedad y Mercantiles de España (Spanish Association of Land and Business Companies Registrars). It is a non-profit institution that brings together all the registrars who develop their activity in Spain.

This institution coordinates the collection of information included in the databases from the Land Registries and provides quarterly and annual data to the unit responsible of this Statistics of Soil Prices in the Ministerio de Fomento, in a magnetic device and with a predetermined registration design, according to the statistics aims and in the agreed deadlines. Before sending the information, the Association carries out a previous activity of data consistency and validation.

Once the information is available for the responsible unit, an exhaustive analysis of data is developed, in order to detect and mend mistakes. Different methods are used, depending on the type of mistake.

- The analysis unit is the piece of land of urban soil or building land.

- The study population is composed of all pieces of land that have been recorded as urban or building land in a certain quarter. The population varies in each quarter since it depends on the number of transactions developed in the referred period. 


\section{Gómez Riocerezo}

- El ámbito geográfico de la estadística comprende todo el territorio nacional, incluidas las Ciudades Autónomas de Ceuta y Melilla.

- La estadística se lleva a cabo con carácter trimestral y el período de referencia de los datos solicitados y tratados es el trimestre en el que se efectuado la transacción, independientemente del trimestre en que se realizó su inscripción en el Registro de la Propiedad.

\section{Variables}

Los registros que corresponden a cada uno de los terrenos registrados, tienen la misma estructura y están compuestos por las siguientes variables:

- Identificación de la operación

- Registro de la Propiedad

- Código provincial

- Código municipal

- Titular del bien

- Fecha de transmisión

- Fecha de inscripción en el Registro de la Propiedad

- Superficie

- Precio

La variable 'identificación de la operación' es una variable numérica que identifica cada transmisión.

La variable 'registro de la propiedad' es una variable numérica que identifica al Registro de la Propiedad que ha efectuado la transmisión.

Los códigos provincial y municipal, de acuerdo con la codificación del Instituto Nacional de Estadística, permiten localizar geográficamente la observación dentro del territorio nacional, es decir, su asignación a una Comunidad Autónoma, provincia y municipio.
- The geographical area covers the whole country, including Ceuta and Melilla.

- The statistics is quarterly developed and the reference period for the demanded and processed data is the quarter in which the transaction has been developed, independently of the quarter this was recorded in the Land Registry.

\section{Variables}

The entries corresponding to each of the recorded pieces of land have the same structure and are composed of the following variables:

- Identification of the operation

- Land Registry

- Province code

- Municipality code

- Owner of the asset

- Date of transfer

- Date of entry in the Land Registry

- Area

- Price

The variable 'identification of the operation' is a numerical variable which identifies each transfer.

The variable 'Land Registry' is a numerical variable which identifies the Land Registry where the transfer has been made.

The province and municipality codes, according to the Spanish Statistics Institute classification, allow the geographical location in the Spanish area, that is, its allocation to a region, province and municipality. 
La variable 'titular del bien' clasifica a los solares según si la persona que lo adquiere es persona física o jurídica.

La 'fecha de transmisión' especifica el momento en el que el solar ha sido transmitido.

La 'fecha de inscripción' se refiere al momento en el que la transmisión se inscribe en el Registro de la Propiedad.

El 'precio' es el valor del solar que ha sido inscrito en el Registro de la Propiedad correspondiente.

La 'superficie' nos indica los metros cuadrados del solar.

Con el objeto de reducir la dispersión de la variable valor de tasación respecto a su media, es preciso construir un determinado número de estratos, donde se agrupen aquellas observaciones cuyos valores tengan una menor dispersión respecto a su media.

La heterogeneidad es una de las características del suelo, de ahí que la agrupación de las observaciones según el tamaño de las parcelas y de los municipios nos permita introducir una mayor homogeneidad en las observaciones correspondientes con el fin de estimar los precios del metro cuadrado en cada uno de los estratos definidos.

En el cuadro siguiente se definen los estratos poblacionales:
The variable 'owner of the asset' classifies land depending on whether the purchaser is a person or a firm.

The variable 'date of transfer' indicates the moment when the piece of land has been transferred.

The 'date of entry' refers to the moment when the transfer is recorded in the Land Registry.

The 'price' is the value of the piece of land which has been recorded in the respective Land Registry.

The 'area' specifies the square metres of the piece of land.

In order to reduce the dispersion of the variable value of appraisal with respect to its mean value, it is necessary to build a certain number of strata, which will group those units whose dispersion to their mean is lower.

Heterogeneity is one of the features of soil. Thus, the grouping of observations according to the size of the pieces of land and municipalities allows us to introduce a higher homogeneity in the corresponding observations, in order to estimate the square metre prices in each of the defined strata.

The table below shows the population strata:

\begin{tabular}{|c|c|}
\hline \multicolumn{2}{|c|}{ Agrupación municipal / Municipalities classification } \\
\hline Estrato / Stratum & $\begin{array}{c}\text { Municipio según su población ( } \mathbf{n}^{0} \text { de habitantes) } \\
\text { Municipality population (inhabitants) }\end{array}$ \\
\hline 1 & $<1.000$ \\
\hline 2 & $1.000-5.000$ \\
\hline 3 & $5.001-10.000$ \\
\hline 4 & $10.001-50.000$ \\
\hline 5 & $>50.000$ \\
\hline
\end{tabular}


La estatificación de la variable superficie sería la siguiente: / Regarding the variable 'area', the strata are the following:

\begin{tabular}{|c|c|}
\hline \multicolumn{2}{|c|}{ Agrupación de la superficie / Area classification } \\
\hline Estrato / Stratum & Superficie en $\mathbf{~ m}^{2}$ / Area $\left(\mathbf{m}^{2}\right)$ \\
\hline 1 & $<500 \mathrm{~m}^{2}$ \\
\hline 2 & $501-1.000 \mathrm{~m}^{2}$ \\
\hline 3 & $1.001-5.000 \mathrm{~m}^{2}$ \\
\hline 4 & $5.001-10.000 \mathrm{~m}^{2}$ \\
\hline 5 & $>10.000 \mathrm{~m}^{2}$ \\
\hline
\end{tabular}

\subsection{Estimación de precios}

En cada estrato de superficie $k$ de la zona geográfica $z$ en el período $t$ se define la variable bidimensional $(X, Y)$ donde $X$ representa el valor del terreno en euros, e $Y$ representa la superficie del terreno en metros cuadrados.

El precio por metro cuadrado de suelo urbano en el estrato de superficie $k$ de la zona geográfica $z$ en el período $t$ vendrá definido por el siguiente cociente:

$$
P_{k z}^{t}=\sum_{i} X_{i k z}^{t} / n_{k z}^{t} / \sum_{i} Y_{i k z}^{t} / n_{k z}^{t}
$$

Simplificando, se obtiene

$$
P_{k z}^{t}=\sum_{i} X_{i k z}^{t} / \sum_{i} Y_{i k z}^{t}(6)
$$

Donde:

$P_{k z}^{t} \quad$ es el precio por precio por metro cuadrado (euros $/ \mathrm{m}^{2}$ ) de los terrenos urbanos en el estrato de superficie $k$ de la zona geográfica $z$ en el período $t$,

$\sum_{i} X_{i k z}^{t} / n_{k z}^{t} \quad$ es el valor medio de los terrenos urbanos en el estrato de superficie $k$ de la zona geográfica $z$ en el período $t$,

\subsection{Price estimation}

In each stratum of area $k$ belonging to the geographical area $z$ in the period $t, a$ two-dimensional variable $(X, Y)$ is defined, where $X$ indicates the piece of land value (in Euros) and $Y$ indicates its area measured in square metres.

The square metre price of urban soil in the stratum of area $k$ belonging to the geographical area $z$ in the period $t$ is expressed by the following formulae:

$$
P_{k z}^{t}=\sum_{i} X_{i k z}^{t} / n_{k z}^{t} / \sum_{i} Y_{i k z}^{t} / n_{k z}^{t}
$$

By simplifying the previous expression, this becomes:

$$
P_{k z}^{t}=\sum_{i} X_{i k z}^{t} / \sum_{i} Y_{i k z}^{t}(6)
$$

where:

$P_{k z}^{t}$ is the price per square metre (Euros $/ \mathrm{m}^{2}$ ) of urban pieces of land in the stratum of area $k$ belonging to the geographical area $z$ and in the period $t$,

$\sum_{i} X_{i k z}^{t} / n_{k z}^{t}$ is the mean value of urban pieces of land in the stratum of area $k$ belonging to the geographical area $\mathrm{z}$ and in the period $t$, 
$\sum_{i} Y_{i k z}^{t} / n_{k z}^{t}$ es la superficie media de los terrenos urbanos en el estrato de superficie $k$ de la zona geográfica $z$ en el período $t$.

El precio por metro cuadrado de terreno urbano en la zona $z$ en el período $t$, se obtiene como media aritmética ponderada de los precios por metro cuadrado en cada uno de los estratos $k$ de los terrenos en la zona geográfica $z$ y en el período $t$ :

$$
P_{z}^{t}=\sum_{k} \alpha_{k z}^{t} P_{k z}^{t}(7)
$$

Donde $\alpha_{k z}^{t}$ representa el número de transacciones en el estrato de superficie $k$ de la zona geográfica $z$ en el período $t$ sobre el número total de transacciones de la zona geográfica $z$ en el período $t$ :

$$
\alpha_{k z}^{t}=n_{k z}^{t} / \sum_{k} n_{k z}^{t}(8)
$$

Donde:

$n_{k z}^{t} \quad$ es el número de transacciones en el estrato de superficie $k$ de la zona geográfica $z$ en el período $t$,

$\sum_{k} n_{k z}^{t}$ es el número total de transacciones de la zona geográfica $z$ en el período $t$.

La suma de los coeficientes de ponderación es la unidad:

$$
\sum_{k} \alpha_{k z}^{t}=1
$$

\section{EVOLUCIÓN DEL SECTOR VIVIENDA Y DEL SECTOR SUELO}

Una vez visto cómo se elaboran los precios de vivienda y de suelo por parte de la Subdirección de Estudios Económicos y Estadísticas del Ministerio de Fomento, pasaremos $\sum_{i} Y_{i k z}^{t} / n_{k z}^{t}$ is the mean area of urban pieces of land in the stratum of area $k$ belonging to the geographical area $z$ and in the period $t$.

The square metre price of urban soil in the geographical area $z$ in the period $t$ is a weighted arithmetic mean of prices in each of the strata $k$ of urban pieces of land in the geographical area $z$ and in the period $t$ :

$$
P_{z}^{t}=\sum_{k} \alpha_{k z}^{t} P_{k z}^{t}(7)
$$

where $\alpha_{k z}^{t}$ indicates the number of transactions in the stratum of area $k$ belonging to the geographical area $z$ and in the period $t$ over the total number of transactions in the geographical area $z$ in the period $t$ :

$$
\alpha_{k z}^{t}=n_{k z}^{t} / \sum_{k} n_{k z}^{t}(8)
$$

where:

$n_{k z}^{t} \quad$ is the number of transactions in the stratum of area $k$ belonging to the geographical area $z$ and in the period $t$,

$\sum_{k} n_{k z}^{t}$ is the number of transactions in the geographical area $z$ and in the period $t$.

The addition of the weight coefficients equals one:

$$
\sum_{k} \alpha_{k z}^{t}=1
$$

\section{EVOLUTION IN HOUSING AND SOIL SECTORS}

Once the procedure of estimating prices of housing and soil by the Subdirección de Estudios Económicos y Estadísticas belonging to the Ministerio de Fomento has been described, we will then analyse 
a hacer un análisis de la evolución de dichos precios desde el año 2004.

\subsection{Sector vivienda}

Respecto a este sector, se diferencia la información en precios de la vivienda y en transacciones inmobiliarias.

En la Tabla 1 se expresan los precios de vivienda libre, vivienda libre nueva, vivienda libre de segunda mano y vivienda protegida desde el año 2004, así como las tasas interanuales correspondientes: the evolution in those prices starting from 2004.

\subsection{Housing sector}

Regarding the housing sector, information is differentiated for prices of housing and real estate transactions.

Table 1 shows prices for free-market housing, for both new and second-hand free-market housing, as well as statesubsidized housing, starting from 2004, together with their corresponding year-onyear rates:

\section{Tábla 1.Precios de vivienda (unidad: euros/ $\mathbf{m}^{2}$ )} Table 1. Housing prices (Euros/ m²)

\begin{tabular}{|c|c|c|c|c|c|c|c|c|c|}
\hline \multirow[b]{2}{*}{$\begin{array}{l}\text { Año } \\
\text { Year }\end{array}$} & \multirow[b]{2}{*}{$\begin{array}{l}\text { Trimestre } \\
\text { Quarter }\end{array}$} & \multicolumn{2}{|c|}{$\begin{array}{l}\text { Vivienda libre } \\
\text { Free-market housing }\end{array}$} & \multicolumn{2}{|c|}{$\begin{array}{l}\text { Vivienda libre nueva } \\
\text { New free-market housing }\end{array}$} & \multicolumn{2}{|c|}{$\begin{array}{l}\text { Vivienda libresegunda } \\
\text { mano/Second-hand free- } \\
\text { market housing }\end{array}$} & \multicolumn{2}{|c|}{$\begin{array}{l}\text { Viviendaprotegida } \\
\text { State-subsidized housing }\end{array}$} \\
\hline & & $\begin{array}{l}\text { Precio } \\
\text { Price }\end{array}$ & $\begin{array}{c}\text { Tasas } \\
\text { anuales/Year } \\
\text {-on-year rate }\end{array}$ & $\begin{array}{l}\text { Precio } \\
\text { Price }\end{array}$ & $\begin{array}{l}\text { Tasas anuales } \\
\text { Year-on-year } \\
\text { rate }\end{array}$ & $\begin{array}{l}\text { Precio } \\
\text { Price }\end{array}$ & $\begin{array}{l}\text { Tasas anuales } \\
\text { Year-on-year } \\
\text { rate }\end{array}$ & $\begin{array}{l}\text { Precio } \\
\text { Price }\end{array}$ & $\begin{array}{l}\text { Tasas anuales } \\
\text { Year-on-year } \\
\text { rate }\end{array}$ \\
\hline \multirow[t]{4}{*}{2004} & $1^{0}$ & $1.456,2$ & & $1.431,8$ & & $1.465,9$ & & & \\
\hline & $2^{0}$ & $1.538,8$ & & $1.524,3$ & & $1.544,0$ & & & \\
\hline & $3^{0}$ & $1.570,8$ & & $1.544,2$ & & $1.581,4$ & & & \\
\hline & $4^{0}$ & $1.618,0$ & & $1.618,6$ & & $1.613,7$ & & & \\
\hline \multirow[t]{4}{*}{2005} & $1^{0}$ & $1.685,4$ & 15,7 & $1.653,3$ & 15,5 & $1.698,6$ & 15,9 & 912,6 & \\
\hline & $2^{0}$ & $1.752,8$ & 13,9 & $1.714,5$ & 12,5 & $1.768,2$ & 14,5 & 916,2 & \\
\hline & $3^{0}$ & $1.781,5$ & 13,4 & $1.742,6$ & 12,8 & $1.800,5$ & 13,9 & 931,8 & \\
\hline & $4^{0}$ & $1.824,3$ & 12,8 & $1.786,2$ & 10,4 & $1.843,7$ & 14,3 & 945,0 & \\
\hline \multirow[t]{4}{*}{2006} & $1^{0}$ & $1.887,6$ & 12,0 & $1.856,7$ & 12,3 & $1.900,7$ & 11,9 & 977,4 & 7,1 \\
\hline & $2^{0}$ & $1.942,3$ & 10,8 & $1.912,9$ & 11,6 & $1.952,4$ & 10,4 & 995,6 & 8,7 \\
\hline & $3^{0}$ & $1.956,7$ & 9,8 & $1.926,1$ & 10,5 & $1.968,7$ & 9,3 & $1.000,2$ & 7,3 \\
\hline & $4^{0}$ & $1.990,5$ & 9,1 & $1.957,5$ & 9,6 & $2.002,6$ & 8,6 & $1.015,7$ & 7,5 \\
\hline \multirow[t]{4}{*}{2007} & $1^{0}$ & $2.024,2$ & 7,2 & $1.993,9$ & 7,4 & $2.035,0$ & 7,1 & $1.020,3$ & 4,4 \\
\hline & $2^{0}$ & $2.054,5$ & 5,8 & $2.028,6$ & 6,0 & $2.062,1$ & 5,6 & $1.035,8$ & 4,0 \\
\hline & $3^{0}$ & $2.061,2$ & 5,3 & $2.036,9$ & 5,8 & $2.068,9$ & 5,1 & $1.053,6$ & 5,3 \\
\hline & $4^{0}$ & $2.085,5$ & 4,8 & $2.069,9$ & 5,7 & $2.085,9$ & 4,2 & $1.071,1$ & 5,5 \\
\hline \multirow[t]{4}{*}{2008} & $1^{0}$ & $2.101,4$ & 3,8 & $2.094,7$ & 5,1 & $2.102,1$ & 3,3 & $1.100,0$ & 7,8 \\
\hline & $2^{0}$ & $2.095,7$ & 2,0 & $2.088,1$ & 2,9 & $2.098,5$ & 1,8 & $1.112,5$ & 7,4 \\
\hline & $3^{0}$ & $2.068,7$ & 0,4 & $2.071,6$ & 1,7 & $2.062,1$ & $-0,3$ & $1.123,4$ & 6,6 \\
\hline & $4^{0}$ & $2.018,5$ & $-3,2$ & $2.022,0$ & $-2,3$ & $2.007,7$ & $-3,7$ & $1.131,6$ & 5,6 \\
\hline \multirow[t]{4}{*}{2009} & $1^{0}$ & $1.958,1$ & $-6,8$ & $1.959,2$ & $-6,5$ & $1.956,8$ & $-6,9$ & $1.112,5$ & 1,1 \\
\hline & $2^{0}$ & $1.920,9$ & $-8,3$ & $1.923,9$ & $-7,9$ & $1.917,7$ & $-8,6$ & $1.096,9$ & $-1,4$ \\
\hline & $3^{0}$ & $1.902,8$ & $-8,0$ & $1.911,1$ & $-7,7$ & $1.890,5$ & $-8,3$ & $1.114,3$ & $-0,8$ \\
\hline & $4^{0}$ & $1.892,3$ & $-6,3$ & $1.899,6$ & $-6,1$ & $1.878,7$ & $-6,4$ & $1.124,3$ & $-0,6$ \\
\hline \multirow[t]{4}{*}{2010} & $1^{0}$ & $1.865,7$ & $-4,7$ & $1.869,9$ & $-4,6$ & $1.863,4$ & $-4,8$ & $1.133,4$ & 1,9 \\
\hline & $2^{0}$ & $1.848,9$ & $-3,7$ & $1.846,7$ & $-4,0$ & $1.854,9$ & $-3,3$ & $1.141,4$ & 4,1 \\
\hline & $3^{0}$ & $1.832,0$ & $-3,7$ & $1.846,7$ & $-3,4$ & $1.827,7$ & $-3,3$ & $1.148,4$ & 3,1 \\
\hline & $4^{0}$ & $1.825,5$ & $-3,5$ & $1.829,9$ & $-3,7$ & $1.819,5$ & $-3,2$ & $1.163,5$ & 3,5 \\
\hline \multirow[t]{4}{*}{2011} & $1^{0}$ & $1.777,6$ & $-4,7$ & $1.793,8$ & $-4,1$ & $1.764,8$ & $-5,3$ & $1.164,9$ & 2,8 \\
\hline & $2^{0}$ & $1.752,1$ & $-5,2$ & $1.770,7$ & $-4,1$ & $1.739,4$ & $-6,2$ & $1.161,7$ & 1,8 \\
\hline & $3^{0}$ & $1.729,3$ & $-5,6$ & $1.747,5$ & $-5,4$ & $1.719,0$ & $-5,9$ & $1.158,1$ & 0,8 \\
\hline & $4^{0}$ & $1.701,8$ & $-6,8$ & $1.721,1$ & $-5,9$ & $1.691,8$ & $-7,0$ & $1.158,2$ & $-0,5$ \\
\hline 2012 & $1^{0}$ & $1.649,3$ & $-7,2$ & $1.671,5$ & $-6,8$ & $1.637,5$ & $-7,2$ & $1.150,8$ & $-1,2$ \\
\hline
\end{tabular}


Los resultados que se deducen de esta Tabla son:

- El precio de la vivienda libre en el primer trimestre de 2012 fue de 1.649,3 euros, lo que significa un $3,1 \%$ menos que en el cuarto trimestre de 2011, cuyo valor fue de $1.701,8$ euros. Respecto al primer trimestre de 2011, dicho valor correspondía a 1.777,6 euros, lo que representa un $7,2 \%$ menos.

- El precio de la vivienda libre nueva en el primer trimestre de 2012 fue de 1.671,5 euros, un $2,9 \%$ menos que en el cuarto trimestre de 2011, que fue de 1.721,1 euros, y un $6,8 \%$ menos que en el primer trimestre de 2011, que fue de 1.793,8 euros.

- El precio de la vivienda libre de segunda mano en el primer trimestre de 2012 fue de $1.637,5$ euros, un $3,2 \%$ menos que en el cuarto trimestre de 2011, que fue de $1.691,8$ euros, y un $7,2 \%$ menos que en el primer trimestre de 2011, que fue de $1.764,8$ euros.

Gráficamente, se observa a continuación, la evolución de los precios de vivienda libre y de las tasas interanuales correspondientes.
From the Table above, we draw the following results:

- The price of free-market housing in the first quarter of 2012 was 1,649.3 Euros, which means a $3.1 \%$ lower than the price in the last quarter of 2011, when it was 1,701.8 Euros. Regarding the first quarter of 2011, the price was 1,778.6 Euros, which means that in the same period in 2012 it was a $7.2 \%$ lower.

- The price of new free-market housing in the first quarter of 2012 was 1,671.5 Euros, which is a $2.9 \%$ lower than in the fourth quarter of 2011, when the price was 1,721.1 Euros, and a $6.8 \%$ lower than in the first quarter of 2011, when it was 1,793.8 Euros.

- The price of second hand free-market housing in the first quarter of 2012 was $1,637.5$ Euros, which is a $3.2 \%$ lower than in the fourth quarter of 2011, when the price was 1,691.8 Euros, and a 7.2\% lower than in the first quarter of 2011, when it was 1,764.8 Euros.

Below we graphically show the evolution in prices of free-market housing, as well as their corresponding year-on-year rates.

\section{Gráfico 1. Precios de vivienda libre / Graph 1. Free-market housing prices}

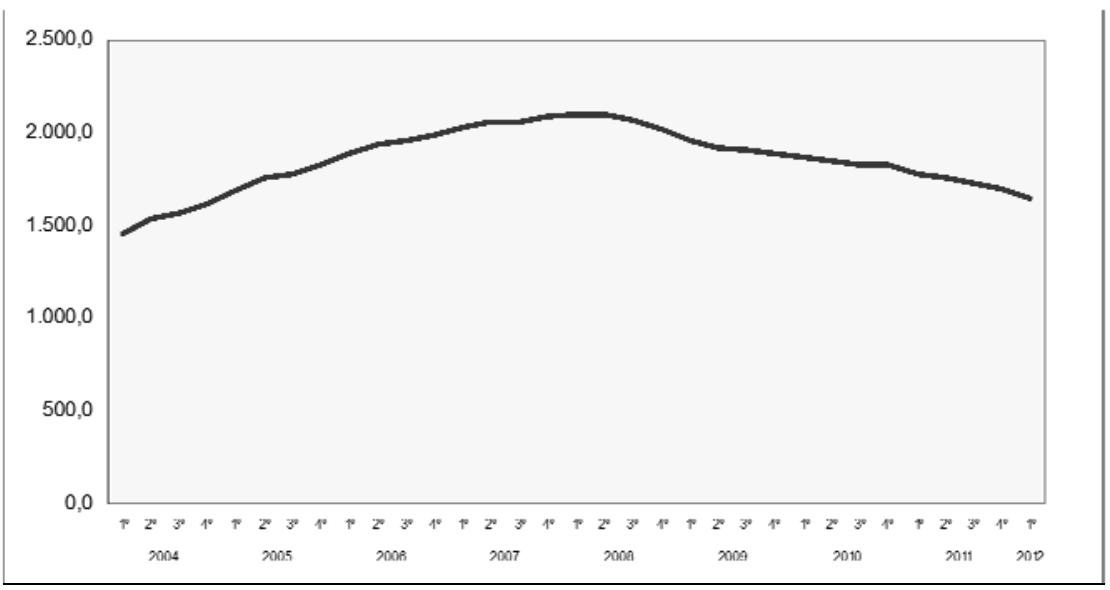


Se comprueba fácilmente que desde el año 2004 hasta principios de 2008 los precios suben, momento a partir del cual los precios empiezan a bajar. Se aprecia idéntico resultado al observar el gráfico de las tasas interanuales correspondientes que aparece a continuación.
It can be easily seen that prices rise from 2004 to the beginning of 2008, when they start to fall. The same trend is observed regarding the year-on-year rates, whose evolution is shown in the graph below.

\section{Gráfico 2. Tasas interanuales de precios de vivienda libre Graph 2. Year-on-year rates of free-market housing prices}

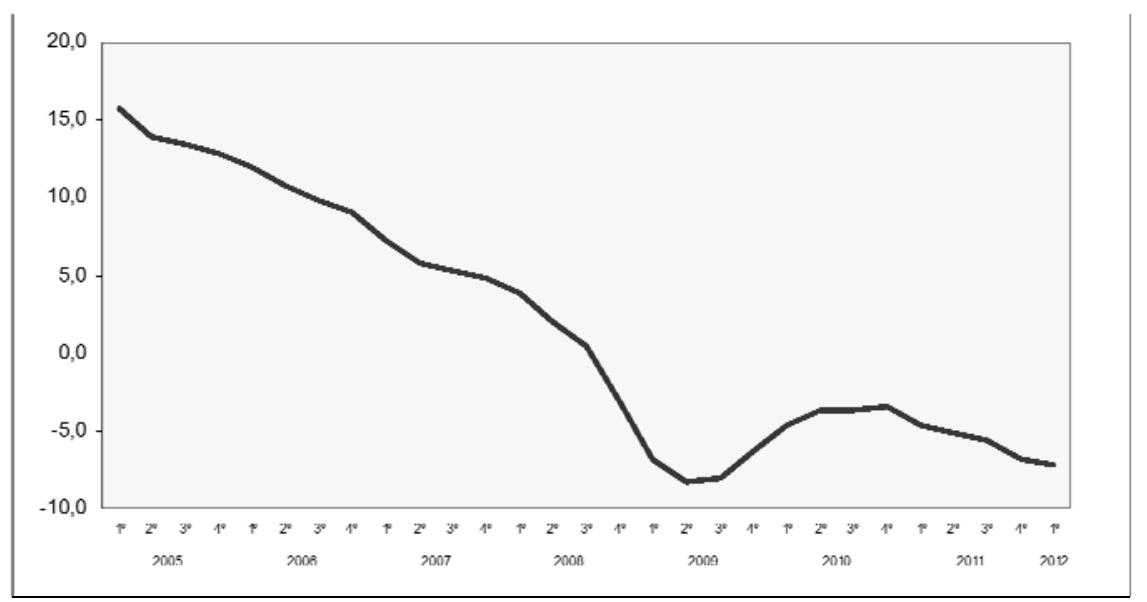

Los datos que se presentan en la Tabla 2 corresponden a las transacciones inmobiliarias, y de ellos se deduce:

- En el primer trimestre de 2012 el número total de transacciones inmobiliarias ha sido de 70.228 , lo que significa un $34,6 \%$ menos que en el cuarto trimestre de 2011, cuyo número fue de 107.373; asimismo y, respecto al primer trimestre de 2011, cuyo valor fue de 74.455, el porcentaje correspondiente es de un $5,7 \%$ menos.

- Por su parte, el número total de transacciones inmobiliarias de vivienda libre nueva en el primer trimestre de 2012 fue de 13.721, un 59,9\% menos que en el cuarto trimestre de 2011, que fue de 34.248 , y un $34,8 \%$ menos que en el primer trimestre de 2011, que fue de 21.055.
Data shown in Table 2 refer to the real estate transactions. From them, the following conclusions are drawn:

- On the one hand, in the first quarter of 2012 the total number of real estate transactions was 70,228 , which means it was a $34.6 \%$ lower than in the last quarter of 2011, when 107,373 transactions were developed. Likewise, the number was a $5.7 \%$ lower than in the first quarter of 2011, when the number of transactions was 74,455 .

- On the other hand, the total number of real estate transactions related to new free-market housing in the first quarter of 2012 was 13,721, which is a $59.9 \%$ lower than in the last quarter of 2011, when the number was 34,248, and a $34,8 \%$ lower than in the first quarter of that year, when it was 21,055. 
- En relación al número total de transacciones inmobiliarias de vivienda libre de segunda mano en el primer trimestre de 2012 fue de 50.325, un $15,5 \%$ menos que en el cuarto trimestre de 2011, que fue de 59.567, y un $10,1 \%$ más que en el primer trimestre de 2011, que fue de 45.725 .
- With regard to the total number of real estate transactions related to secondhand free-market housing, in the first quarter of 2012 it was 50,325, which means a $15.5 \%$ lower than in the fourth quarter of 2011, when the total number of transactions was 59,567, and a $10.1 \%$ higher than in the first quarter of 2011, when it was 45,725.

Tabla 2. Número de transacciones inmobiliarias Table 2. Number of real estate transactions

\begin{tabular}{|c|c|c|c|c|c|c|c|}
\hline \multirow[b]{2}{*}{$\begin{array}{l}\text { Año } \\
\text { Year }\end{array}$} & \multirow[b]{2}{*}{$\begin{array}{l}\text { Trimestre } \\
\text { Quarter }\end{array}$} & \multicolumn{2}{|c|}{$\begin{array}{l}\text { Número total de } \\
\text { transacciones/Total number } \\
\text { of transactions }\end{array}$} & \multicolumn{2}{|c|}{$\begin{array}{l}\text { Vivienda libre nueva } \\
\text { New free-market housing }\end{array}$} & \multicolumn{2}{|c|}{$\begin{array}{l}\text { Vivienda libre segunda } \\
\text { mano/Second-hand free- } \\
\text { market housing }\end{array}$} \\
\hline & & $\begin{array}{c}\text { Transacciones } \\
\text { Transactions }\end{array}$ & $\begin{array}{c}\text { Tasas } \\
\text { anuales } \\
\text { Year-on-year } \\
\text { rate }\end{array}$ & $\begin{array}{c}\text { Transacciones } \\
\text { Transactions }\end{array}$ & $\begin{array}{c}\text { Tasas } \\
\text { anuales } \\
\text { Year-on- } \\
\text { year rate }\end{array}$ & $\begin{array}{c}\text { Transacciones } \\
\text { Transactions }\end{array}$ & $\begin{array}{c}\text { Tasas } \\
\text { anuales } \\
\text { Year-on- } \\
\text { year rate }\end{array}$ \\
\hline \multirow[t]{4}{*}{2004} & $1^{0}$ & \begin{tabular}{|l|}
190.442 \\
\end{tabular} & & 58.292 & & 120.328 & \\
\hline & $2^{\circ}$ & 223.895 & & 70.827 & & 141.641 & \\
\hline & $3^{\circ}$ & 201.089 & & 66.171 & & 124.720 & \\
\hline & $4^{\circ}$ & 232.964 & & 72.250 & & 147.466 & \\
\hline \multirow[t]{4}{*}{2005} & $1^{0}$ & 196.438 & 3,1 & 60.950 & 4,6 & 125.717 & 4,5 \\
\hline & $2^{\circ}$ & 241.398 & 7,8 & 80.216 & 13,3 & 148.922 & 5,1 \\
\hline & $3^{0}$ & 216.333 & 7,6 & 82.842 & 25,2 & 122.405 & $-1,9$ \\
\hline & $4^{\circ}$ & 247.405 & 6,2 & 82.052 & 13,6 & 151.585 & 2,8 \\
\hline \multirow[t]{4}{*}{2006} & $1^{0}$ & 233.669 & 19,0 & 86.358 & 41,7 & 136.363 & 8,5 \\
\hline & $2^{\circ}$ & 251.649 & 4,2 & 94.333 & 17,6 & 145.289 & $-2,4$ \\
\hline & $3^{0}$ & 221.610 & 2,4 & 93.081 & 12,4 & 117.109 & $-4,3$ \\
\hline & $4^{\circ}$ & 248.258 & 0,3 & 103.384 & 26,0 & 132.071 & $-12,9$ \\
\hline \multirow[t]{4}{*}{2007} & $1^{0}$ & 230.755 & $-1,2$ & 89.712 & 3,9 & 122.087 & $-10,5$ \\
\hline & $2^{\circ}$ & 227.562 & $-9,6$ & 93.733 & $-0,6$ & 116.508 & $-19,8$ \\
\hline & $3^{0}$ & 186.504 & $-15,8$ & 86.836 & $-6,7$ & 85.044 & $-27,4$ \\
\hline & $4^{\circ}$ & 192.050 & $-22,6$ & 94.225 & $-8,9$ & 80.719 & $-38,9$ \\
\hline \multirow[t]{4}{*}{2008} & $1^{0}$ & 159.088 & $-31,1$ & 80.448 & $-10,3$ & 65.221 & $-46,6$ \\
\hline & $2^{0}$ & 157.008 & $-31,0$ & 80.378 & $-14,2$ & 61.544 & $-47,2$ \\
\hline & $3^{\circ}$ & 122.949 & $-34,1$ & 67.294 & $-22,5$ & 44.363 & $-47,8$ \\
\hline & $4^{0}$ & 125.419 & $-34,7$ & 63.358 & $-32,8$ & 47.274 & $-41,4$ \\
\hline \multirow[t]{4}{*}{2009} & $1^{0}$ & 104.703 & $-34,2$ & 49.806 & $-38,1$ & 43.289 & $-33,6$ \\
\hline & $2^{\circ}$ & 119.938 & $-23,6$ & 54.227 & $-32,5$ & 52.385 & $-14,9$ \\
\hline & $3^{0}$ & 107.534 & $-12,5$ & 46.250 & $-31,3$ & 50.491 & 13,8 \\
\hline & $4^{0}$ & 131.544 & 4,9 & 51.443 & $-18,8$ & 66.242 & 40,1 \\
\hline \multirow[t]{4}{*}{2010} & $1^{0}$ & 107.079 & 2,3 & 38.837 & $-22,0$ & 57.879 & 33,7 \\
\hline & $2^{0}$ & 153.164 & 27,7 & 59.604 & 9,9 & 78.415 & 49,7 \\
\hline & $3^{0}$ & 80.550 & $-25,1$ & 21.212 & $-54,1$ & 52.736 & 4,4 \\
\hline & $4^{\circ}$ & 150.494 & 14,4 & 45.562 & $-11,4$ & 90.143 & 36,1 \\
\hline \multirow[t]{4}{*}{2011} & $1^{0}$ & 74.455 & $-30,5$ & 21.055 & $-45,8$ & 45.725 & $-21,0$ \\
\hline & $2^{0}$ & 90.756 & $-40,7$ & 22.546 & $-62,2$ & 57.268 & $-27,0$ \\
\hline & $3^{\circ}$ & 76.534 & $-5,0$ & 20.245 & $-4,6$ & 48.484 & $-8,1$ \\
\hline & $4^{0}$ & 107.373 & $-28,7$ & 34.248 & $-24,8$ & 59.567 & $-33,9$ \\
\hline 2012 & $1^{0}$ & 70.228 & $-5,7$ & 13.721 & $-34,8$ & 50.325 & 10,1 \\
\hline
\end{tabular}


En los Gráficos 3, 4 y 5 se expresa la tendencia del número de transacciones inmobiliarias para los tres casos considerados. Siendo, a partir de finales de 2006, la fecha en la que se aprecia un descenso del número de transacciones inmobiliarias de vivienda libre nueva y del número total, mientras que en el caso de viviendas de segunda mano se sigue la misma tendencia descendiente hasta principios de 2009, pero a partir de ese punto tiende a estabilizarse.
Graphs 3, 4 and 5 show the trend of the number of real estate transactions for the three aforementioned cases. It is from the end of 2006 when we observe a fall in the total number of real estate transactions and in the number of transactions related to new free-market housing; in the case of second-hand free-market housing, the same descending trend is observed until the beginning of 2009, but from that point onwards, the number of transactions tends to become stabilized.

\section{Gráfico 3. Número total de transacciones inmobiliarias Graph 3. Number of real estate transactions}

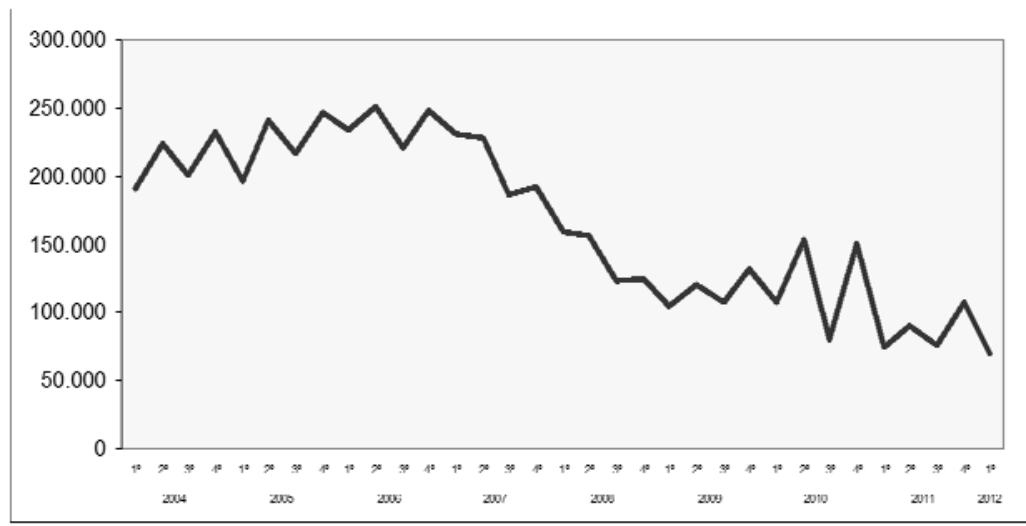

\section{Gráfico 4. Número de transac ciones de vivienda libre nueva Graph 4. Number of new free-market housing transactions}

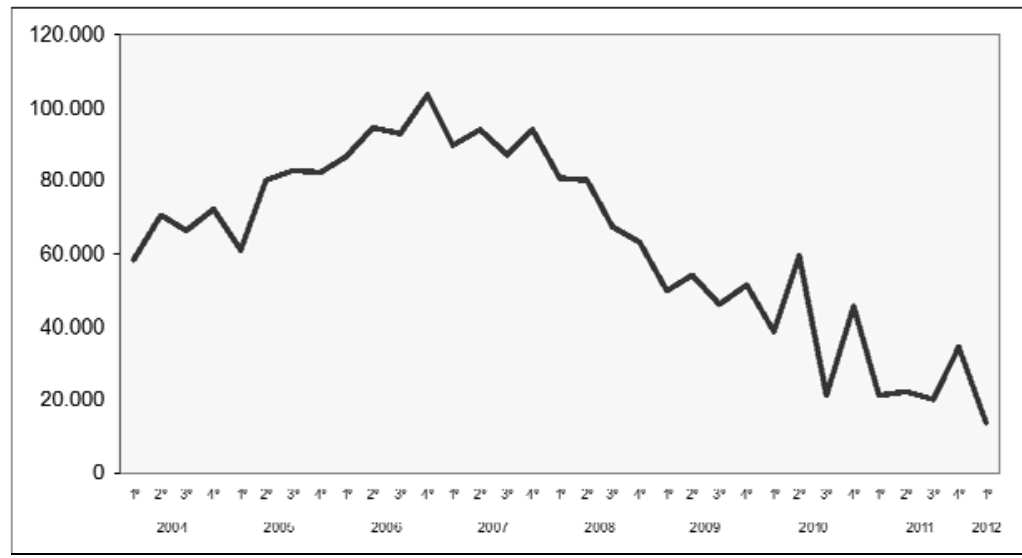




\section{Gráfico 5. Número de transacciones de vivienda libre de segunda mano Graph 5. Number of sec ond-hand free-market housing transactions}

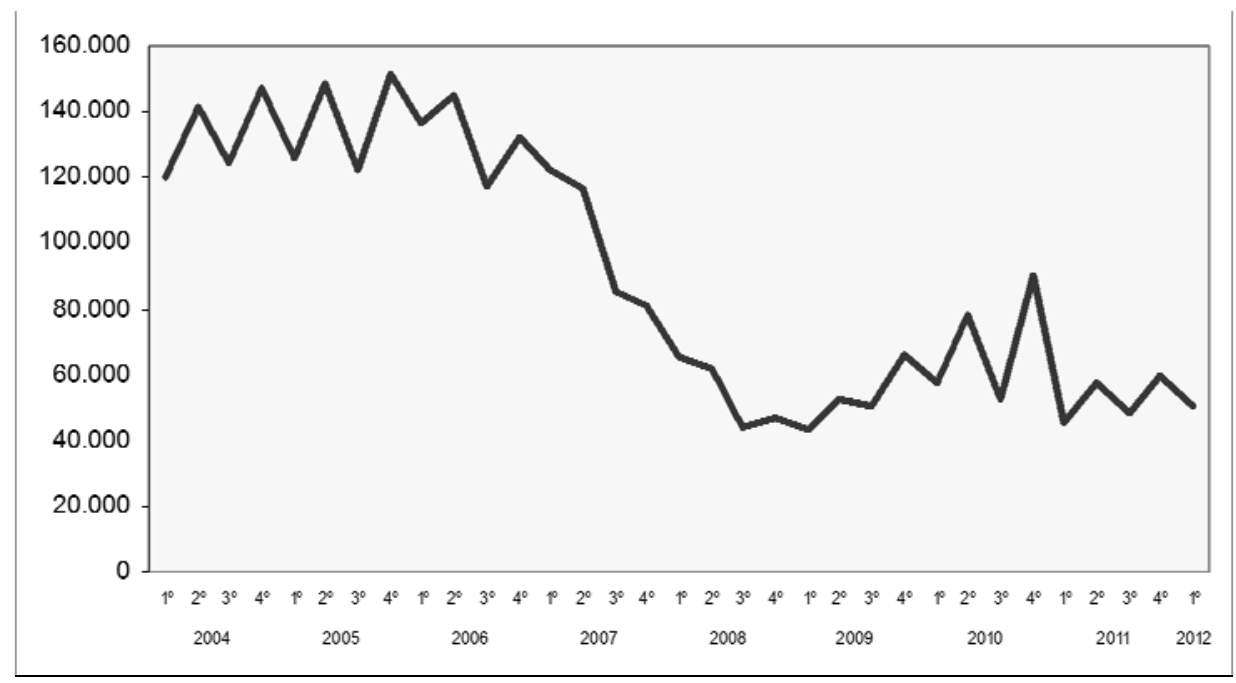

\subsection{Sector suelo}

Siguiendo un procedimiento similar al sector vivienda, se realiza un análisis de la evolución del sector suelo a partir del año 2004, basado en las siguientes variables: precios del suelo, superficie, valor y transacciones de suelo.

- En primer lugar, se presentan en la Tabla 3 los datos relativos a los precios de suelo urbano en España desde 2004, además de las tasas trimestrales y anuales. Gráficamente estos resultados se pueden observar en los Gráficos 6 y 7.

\subsection{Soil sector}

Following a similar procedure to the housing sector, we carry out an analysis of the evolution in the soil sector since 2004, in which the variables are: soil prices, area, value and soil transactions.

- First, Table 3 shows the data related to urban soil prices in Spain from 2004, together with quarter-on-quarter and year-on-year rates. From a graphical viewpoint, the results can be observed in Graphs 6 and 7.

\section{Tábla 3. Precios de suelo (unidad: euros/ $\mathbf{m}^{2}$ ) / Table 3. Soil prices (Euros/ $\mathbf{m}^{2}$ )}

\begin{tabular}{|c|c|c|c|c|}
\hline $\begin{array}{c}\text { Año } \\
\text { Year }\end{array}$ & $\begin{array}{c}\text { Trimestre } \\
\text { Quarter }\end{array}$ & $\begin{array}{c}\text { Precio suelo } \\
\text { Soil price }\end{array}$ & $\begin{array}{c}\text { Tasas trimestrales } \\
\text { Quarter-on-quarter rates }\end{array}$ & $\begin{array}{c}\text { Tasas anuales } \\
\text { Year-on-year rates }\end{array}$ \\
\hline 2004 & $\mathbf{1}^{\mathbf{0}}$ & 206,5 & & \\
& $\mathbf{2}^{\circ}$ & 226,4 & 9,6 & \\
& $\mathbf{3}^{\circ}$ & 227,1 & 0,3 & \\
\hline & $4^{0}$ & 247,3 & 8,9 & \\
\hline
\end{tabular}


Pecunia, Monográfico (2012), 137-164

M. Gómez Riocerezo

\begin{tabular}{|c|c|c|c|c|}
\hline 2005 & $1^{0}$ & 258,6 & 4,6 & 25,2 \\
\hline & $2^{\circ}$ & 254,5 & $-1,6$ & 12,4 \\
\hline & $3^{\circ}$ & 263,9 & 3,7 & 16,2 \\
\hline & $4^{\circ}$ & 267,3 & 1,3 & 8,1 \\
\hline \multirow[t]{4}{*}{2006} & $1^{0}$ & 257,4 & $-3,7$ & $-0,5$ \\
\hline & $2^{\circ}$ & 258,4 & 0,4 & 1,5 \\
\hline & $3^{\circ}$ & 273,7 & 5,9 & 3,7 \\
\hline & $4^{0}$ & 284,6 & 4,0 & 6,5 \\
\hline \multirow[t]{4}{*}{2007} & $1^{0}$ & 271,8 & $-4,5$ & 5,6 \\
\hline & $2^{\circ}$ & 280,6 & 3,2 & 8,6 \\
\hline & $3^{0}$ & 285,0 & 1,6 & 4,1 \\
\hline & $4^{0}$ & 277,0 & $-2,8$ & $-2,7$ \\
\hline \multirow[t]{4}{*}{2008} & $1^{0}$ & 250,9 & $-9,4$ & $-7,7$ \\
\hline & $2^{\circ}$ & 258,8 & 3,1 & $-7,8$ \\
\hline & $3^{0}$ & 257,1 & $-0,7$ & $-9,8$ \\
\hline & $4^{0}$ & 248,0 & $-3,5$ & $-10,5$ \\
\hline \multirow[t]{4}{*}{2009} & $1^{0}$ & 238,8 & $-3,7$ & $-4,8$ \\
\hline & $2^{\circ}$ & 247,6 & 3,7 & $-4,3$ \\
\hline & $3^{\circ}$ & 237,7 & $-4,0$ & $-7,5$ \\
\hline & $4^{0}$ & 232,0 & $-2,4$ & $-6,5$ \\
\hline \multirow[t]{4}{*}{2010} & $1^{0}$ & 204,7 & $-11,8$ & $-14,3$ \\
\hline & $2^{\circ}$ & 210,7 & 2,9 & $-14,9$ \\
\hline & $3^{\circ}$ & 190,8 & $-9,5$ & $-19,7$ \\
\hline & $4^{\circ}$ & 227,7 & 19,4 & $-1,9$ \\
\hline \multirow[t]{4}{*}{2011} & $1^{0}$ & 212,4 & $-6,7$ & 3,7 \\
\hline & $2^{\circ}$ & 213,9 & 0,7 & 1,5 \\
\hline & $3^{\circ}$ & 169,6 & $-20,7$ & $-11,1$ \\
\hline & $4^{0}$ & 182,5 & 7,6 & $-19,8$ \\
\hline 2012 & $1^{0}$ & 177,6 & $-2,7$ & $-16,4$ \\
\hline
\end{tabular}

\section{Gráfico 6. Precios de suelo urbano en España}

\section{Graph 6. Urban soil prices in Spain}

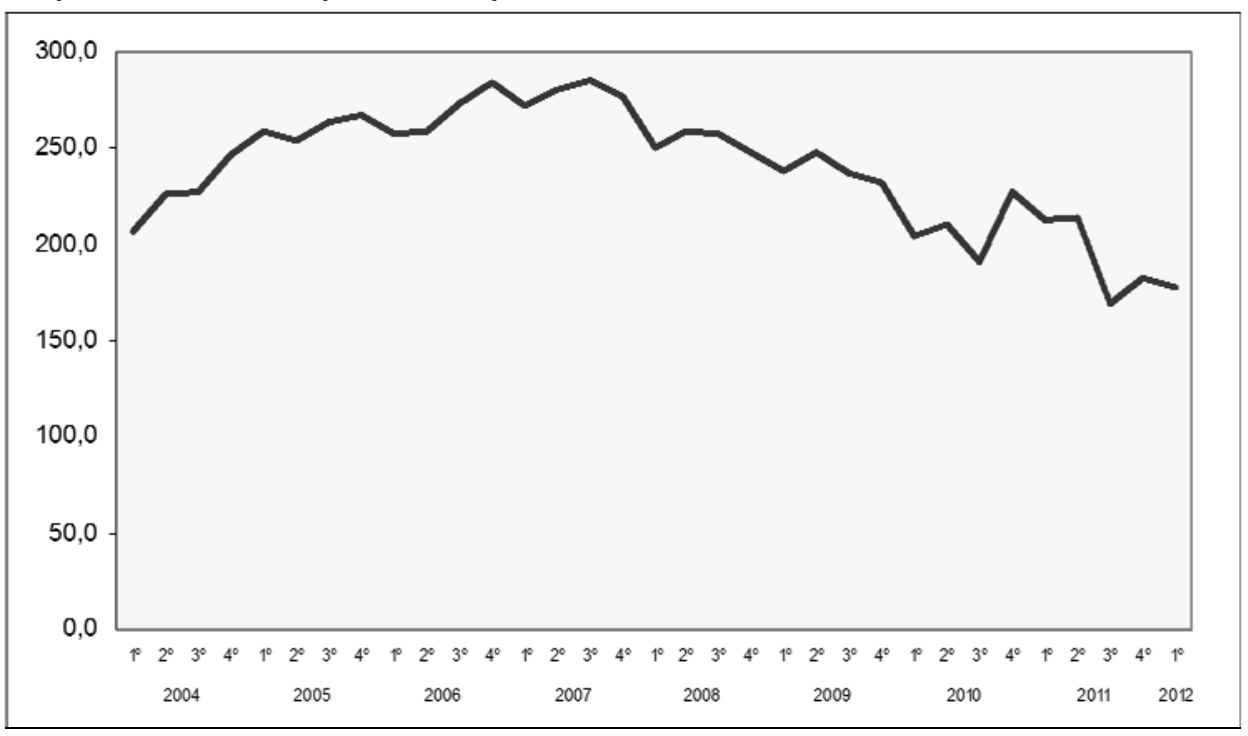




\section{Gráfico 7. Tasas interanuales de prec ios de suelo Graph 7. Year-on-year rates of urban soil prices}

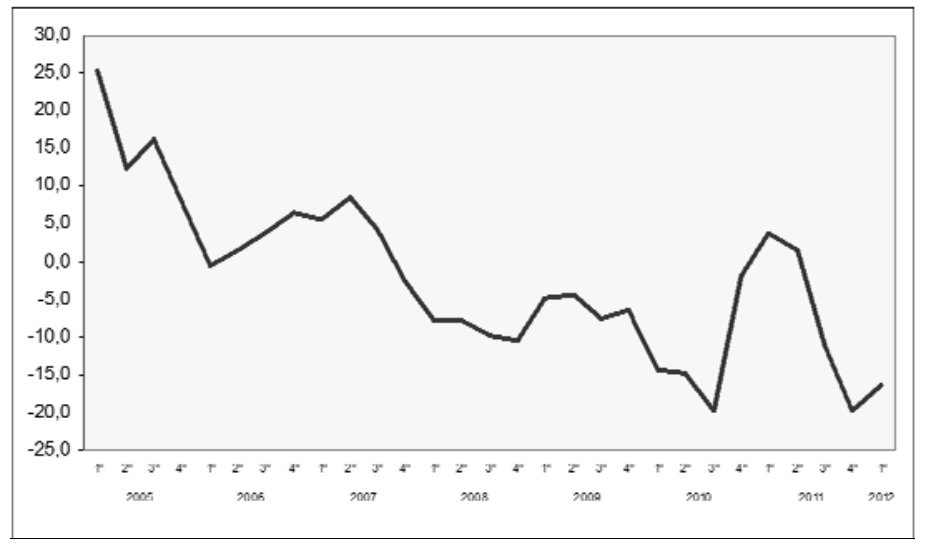

Se deduce que el precio medio del metro cuadrado de suelo urbano en el primer trimestre de 2012 fue de 177,6 euros, un $16,4 \%$ menos que en el mismo trimestre de 2011 y un $2,7 \%$ menos que en el cuarto trimestre de 2011.

Como puede comprobarse, es a finales de 2007 cuando se aprecia una tendencia descendente de los precios de suelo urbano en España, aspecto que también se observa en el gráfico correspondiente a las tasas interanuales.

En la Tabla 4 se presentan los datos relativos al valor total de suelo transmitido y a la superficie total de suelo transmitido desde el año 2004. De la misma forma que las variables correspondientes al sector vivienda, en los Gráficos 8 y 9 se puede observar la evolución del valor total y de la superficie total, ambas correspondientes a suelo transmitido.

Se observa que la superficie transmitida en el primer trimestre de 2012 representó 4,6 millones de metros cuadrados, un 15,2\% menos que los 5,5 millones de metros cuadrados del primer trimestre de $2011 \mathrm{y}$ un $22,6 \%$ menos que el cuarto trimestre de 2011.
It is deduced that the mean square metre price of urban soil in the first quarter of 2012 was 177.6 Euros, which is a $16.4 \%$ lower than in the same quarter of 2011 and a $2.7 \%$ lower than in the last quarter of that year.

As it can be seen, it is at the end of 2007 when there is a descending trend in urban soil prices in Spain, which can also be seen in Graph 7, related to the quarter-onquarter rates.

Table 4 shows data concerning the total value of soil being transferred and its total area starting from 2004. In the same sense as the variables corresponding to the housing sector, Graphs 8 and 9 show the evolution in total value and area of transferred soil.

It is observed that the transferred area in the first quarter of 2012 involved 4.6 million of square metres, which is a $15.2 \%$ lower than 5.5 million of square metres that were transferred in the first quarter of 2011 and a $22.6 \%$ lower than in the last quarter of the same year. 
El valor del suelo transmitido fue de 582,9 millones de euros, un 32,9\% menos respecto al primer trimestre de 2011 (868,1 millones de euros) y un $34,4 \%$ menos que el cuarto trimestre de 2011.

Respecto a la evolución del valor total de suelo urbano transmitido y de la superficie total de suelo urbano transmitido, se aprecia, en ambos casos, un descenso de la tendencia a lo largo de los años.
The value of transferred soil was 582.9 million Euros, which is a $32.9 \%$ lower than the value for the first quarter of 2011 (868.1 million Euros) and a 34.4\% lower than the last quarter of this year.

Regarding the evolution of the total transferred urban soil value and the total area of the transferred urban soil, it is observed, in both cases, a decrease in the trend with the passing of time.

Tabla 4. Superficie y valor de suelo / Table 4. Soil area and value

\begin{tabular}{|c|c|c|c|c|c|c|c|}
\hline \multirow[b]{2}{*}{$\begin{array}{l}\text { Año } \\
\text { Year }\end{array}$} & \multirow[b]{2}{*}{$\begin{array}{c}\text { Trimestre } \\
\text { Quarter }\end{array}$} & \multicolumn{3}{|c|}{ Valor I Value } & \multicolumn{3}{|c|}{ Superficie / Areas } \\
\hline & & $\begin{array}{l}\text { Valor (miles de } \\
\text { euros) } \\
\text { Value (thousand } \\
\text { euros) }\end{array}$ & $\begin{array}{c}\text { Tasas } \\
\text { trimestrales } \\
\text { Quarter-on- } \\
\text { quarter rates } \\
\end{array}$ & $\begin{array}{c}\text { Tasas } \\
\text { anuales } \\
\text { Year-on-year } \\
\text { rates } \\
\end{array}$ & $\begin{array}{c}\text { Superficie } \\
\text { miles de } \mathrm{m}^{2} \\
\text { Areas } \\
\text { thousand } \mathrm{m}^{2}\end{array}$ & $\begin{array}{c}\text { Tasas } \\
\text { trimestrales } \\
\text { Quarter-on- } \\
\text { quarter rates } \\
\end{array}$ & $\begin{array}{c}\text { Tasas } \\
\text { anuales } \\
\text { Year-on- } \\
\text { year rates }\end{array}$ \\
\hline \multirow[t]{4}{*}{2004} & $1^{\circ}$ & 5368707,6 & & & 28465,2 & & \\
\hline & $2^{0}$ & 5678322,7 & 5,8 & & 30388,2 & 6,8 & \\
\hline & $3^{\circ}$ & 4882934,3 & $-14,0$ & & 24913,6 & $-18,0$ & \\
\hline & $4^{0}$ & 7085241,3 & 45,1 & & 33071,5 & 32,7 & \\
\hline \multirow[t]{4}{*}{2005} & $1^{0}$ & 5546449,6 & $-21,7$ & 3,3 & 23829,7 & $-27,9$ & $-16,3$ \\
\hline & $2^{\circ}$ & 6540225,7 & 17,9 & 15,2 & 33505,1 & 40,6 & 10,3 \\
\hline & $3^{0}$ & 5926083,4 & $-9,4$ & 21,4 & 25581,3 & $-23,6$ & 2,7 \\
\hline & $4^{\circ}$ & 4469969,7 & $-24,6$ & $-36,9$ & 20007,9 & $-21,8$ & $-39,5$ \\
\hline \multirow[t]{4}{*}{2006} & $1^{0}$ & 4186788,5 & $-6,3$ & $-24,5$ & 18917,8 & $-5,4$ & $-20,6$ \\
\hline & $2^{\circ}$ & 3890382,7 & $-7,1$ & $-40,5$ & 23384,9 & 23,6 & $-30,2$ \\
\hline & $3^{0}$ & 3371871,7 & $-13,3$ & $-43,1$ & 16369,4 & $-30,0$ & $-36,0$ \\
\hline & $4^{0}$ & 4756144,3 & 41,1 & 6,4 & 22083,2 & 34,9 & 10,4 \\
\hline \multirow[t]{4}{*}{2007} & $1^{0}$ & 5330805,9 & 12,1 & 27,3 & 19328,1 & $-12,5$ & 2,2 \\
\hline & $2^{0}$ & 6368256,3 & 19,5 & 63,7 & 20579,5 & 6,5 & $-12,0$ \\
\hline & $3^{\circ}$ & 4694289,0 & $-26,3$ & 39,2 & 15730,3 & $-23,6$ & $-3,9$ \\
\hline & $4^{0}$ & 4210696,5 & $-10,3$ & $-11,5$ & 13810,4 & $-12,2$ & $-37,5$ \\
\hline \multirow[t]{4}{*}{2008} & $1^{0}$ & 4245916,7 & 0,8 & $-20,4$ & 14930,1 & 8,1 & $-22,8$ \\
\hline & $2^{\circ}$ & 2707490,6 & $-36,2$ & $-57,5$ & 10101,8 & $-32,3$ & $-50,9$ \\
\hline & $3^{0}$ & 3836866,6 & 41,7 & $-18,3$ & 12714,5 & 25,9 & $-19,2$ \\
\hline & $4^{0}$ & 3052507,1 & $-20,4$ & $-27,5$ & 11001,9 & $-13,5$ & $-20,3$ \\
\hline \multirow[t]{4}{*}{2009} & $1^{0}$ & 2571122,4 & $-15,8$ & $-39,4$ & 8716,7 & $-20,8$ & $-41,6$ \\
\hline & $2^{\circ}$ & 2662399,7 & 3,6 & $-1,7$ & 9687,5 & 11,1 & $-4,1$ \\
\hline & $3^{\circ}$ & 2036690,4 & $-23,5$ & $-46,9$ & 6107,2 & $-37,0$ & $-52,0$ \\
\hline & $4^{\circ}$ & 1214462,0 & $-40,4$ & $-60,2$ & 6422,6 & 5,2 & $-41,6$ \\
\hline \multirow[t]{4}{*}{2010} & $1^{0}$ & 1010482,0 & $-16,8$ & $-60,7$ & 5536,4 & $-13,8$ & $-36,5$ \\
\hline & $2^{\circ}$ & 1061295,5 & 5,0 & $-60,1$ & 6817,6 & 23,1 & $-29,6$ \\
\hline & $3^{0}$ & 832552,0 & $-21,6$ & $-59,1$ & 5428,5 & $-20,4$ & $-11,1$ \\
\hline & $4^{0}$ & 1066559,0 & 28,1 & $-12,2$ & 5895,1 & 8,6 & $-8,2$ \\
\hline \multirow[t]{4}{*}{2011} & $1^{0}$ & 868103,3 & $-18,6$ & $-14,1$ & 5467,5 & $-7,3$ & $-1,2$ \\
\hline & $2^{\circ}$ & 1064003,2 & 22,6 & 0,3 & 7150,9 & 30,8 & 4,9 \\
\hline & $3^{0}$ & 683369,8 & $-35,8$ & $-17,9$ & 5121,5 & $-28,4$ & $-5,7$ \\
\hline & $4^{0}$ & 888333,8 & 30 & $-16,7$ & 5991,0 & 17 & 1,6 \\
\hline 2012 & $1^{0}$ & 582863,2 & $-34,4$ & $-32,9$ & 4634,9 & $-22,6$ & $-15,2$ \\
\hline
\end{tabular}




\section{Gráfico 8. Valor de suelo / Graph 8. Soil value}

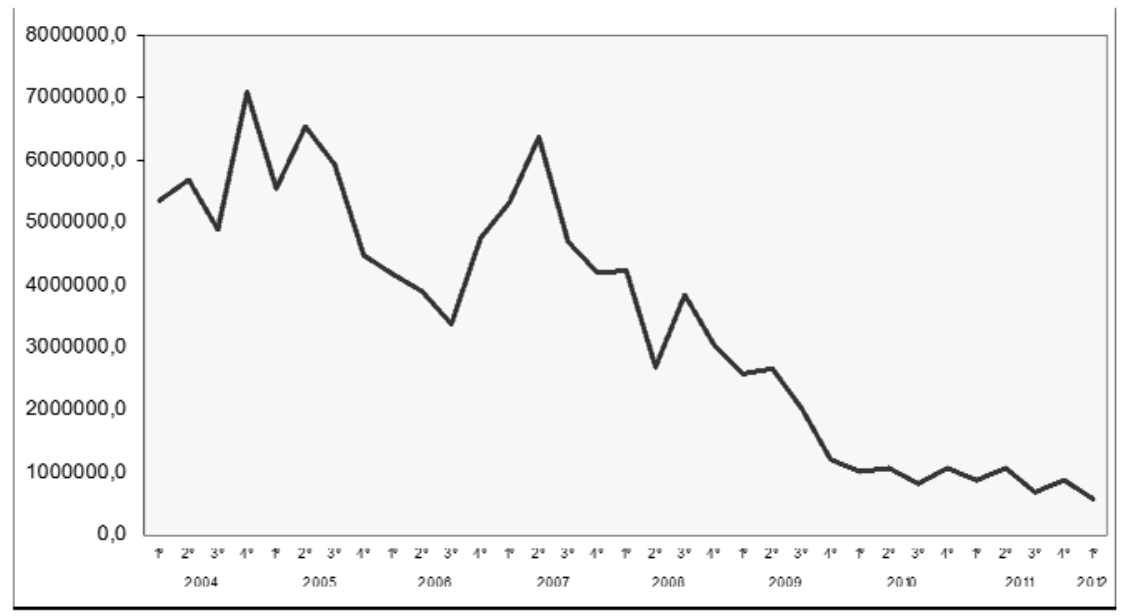

\section{Gráfico 9. Superficie de suelo / Graph 9. Soil area}

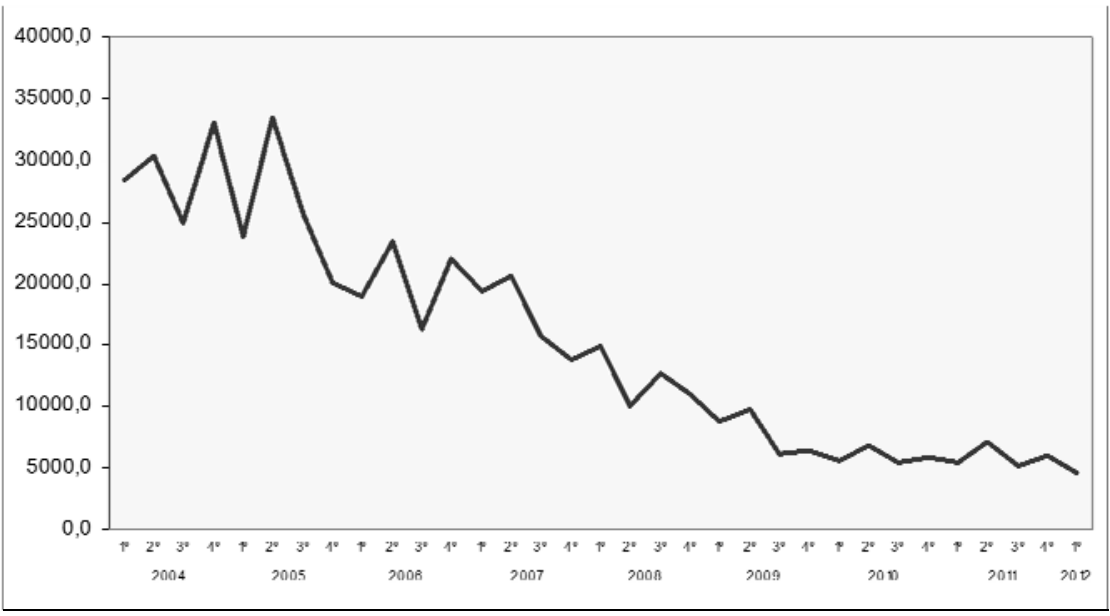

Los datos correspondientes a la última variable considerada para el sector suelo se presentan en la Tabla 5 y se refieren al número total de transacciones de suelo urbano realizadas en España desde 2004. La representación gráfica de dicha variable y la de las tasas interanuales se observa en los Gráficos 10 y 11.
The data corresponding to the last analysed variable for the soil sector are shown in Table 5 and refer to the total number of soil transactions developed in Spain starting from 2004. This variable is graphically presented in Graph 10, whereas Graph 11 shows the evolution in the year-on-year rates. 
Tabla 5. Número de transac ciones de suelo

Table 5. Number of soil transactions

\begin{tabular}{|c|c|c|c|c|}
\hline $\begin{array}{l}\text { Año } \\
\text { Year }\end{array}$ & $\begin{array}{c}\text { Trimestre } \\
\text { Quarter }\end{array}$ & $\begin{array}{l}\text { Transacciones del suelo } \\
\text { Soil transactions }\end{array}$ & $\begin{array}{c}\text { Tasas trimestrales } \\
\text { Quarter-on-quarter rates }\end{array}$ & $\begin{array}{c}\text { Tasas anuales } \\
\text { Year-on-year rates }\end{array}$ \\
\hline \multirow{4}{*}{2004} & $1^{0}$ & 22106 & & \\
\hline & $2^{0}$ & 23030 & 4,2 & \\
\hline & $3^{0}$ & 18206 & $-20,9$ & \\
\hline & $4^{0}$ & 23556 & 29,4 & \\
\hline \multirow{4}{*}{2005} & $1^{0}$ & 19216 & $-18,4$ & $-13,1$ \\
\hline & $2^{0}$ & 23324 & 21,4 & 1,3 \\
\hline & $3^{0}$ & 18012 & $-22,8$ & $-1,1$ \\
\hline & $4^{0}$ & 14986 & $-16,8$ & $-36,4$ \\
\hline \multirow{4}{*}{2006} & $1^{0}$ & 14743 & $-1,6$ & $-23,3$ \\
\hline & $2^{\circ}$ & 15153 & 2,8 & $-35,0$ \\
\hline & $3^{\circ}$ & 12489 & $-17,6$ & $-30,7$ \\
\hline & $4^{0}$ & 16094 & 28,9 & 7,4 \\
\hline \multirow{4}{*}{2007} & $1^{0}$ & 12819 & $-20,3$ & $-13,1$ \\
\hline & $2^{0}$ & 12847 & 0,2 & $-15,2$ \\
\hline & $3^{0}$ & 10361 & $-19,4$ & $-17,0$ \\
\hline & $4^{0}$ & 10410 & 0,5 & $-35,3$ \\
\hline \multirow{4}{*}{2008} & $1^{0}$ & 8892 & $-14,6$ & $-30,6$ \\
\hline & $2^{0}$ & 7956 & $-10,5$ & $-38,1$ \\
\hline & $3^{\circ}$ & 6722 & $-15,5$ & $-35,1$ \\
\hline & $4^{0}$ & 7909 & 17,7 & $-24,0$ \\
\hline \multirow{4}{*}{2009} & $1^{0}$ & 5589 & $-29,3$ & $-37,1$ \\
\hline & $2^{0}$ & 5894 & 5,5 & $-25,9$ \\
\hline & $3^{0}$ & 5023 & $-14,8$ & $-25,3$ \\
\hline & $4^{\circ}$ & 6150 & 22,4 & $-22,2$ \\
\hline \multirow{4}{*}{2010} & $1^{0}$ & 5758 & $-6,4$ & 3,0 \\
\hline & $2^{0}$ & 5997 & 4,2 & 1,7 \\
\hline & $3^{\circ}$ & 4279 & $-28,60$ & $-14,8$ \\
\hline & $4^{0}$ & 5186 & 21,20 & $-15,7$ \\
\hline \multirow{4}{*}{2011} & $1^{0}$ & 4453 & $-14,10$ & $-22,7$ \\
\hline & $2^{0}$ & 4377 & $-1,70$ & -27 \\
\hline & $3^{0}$ & 3546 & $-19,00$ & $-17,1$ \\
\hline & $4^{0}$ & 4420 & 24,60 & $-14,8$ \\
\hline 2012 & $1^{0}$ & 3598 & $-18,60$ & $-19,2$ \\
\hline
\end{tabular}




\section{Gráfico 10. Número de transacc ciones de suelo Graph 10. Number of soil transactions}

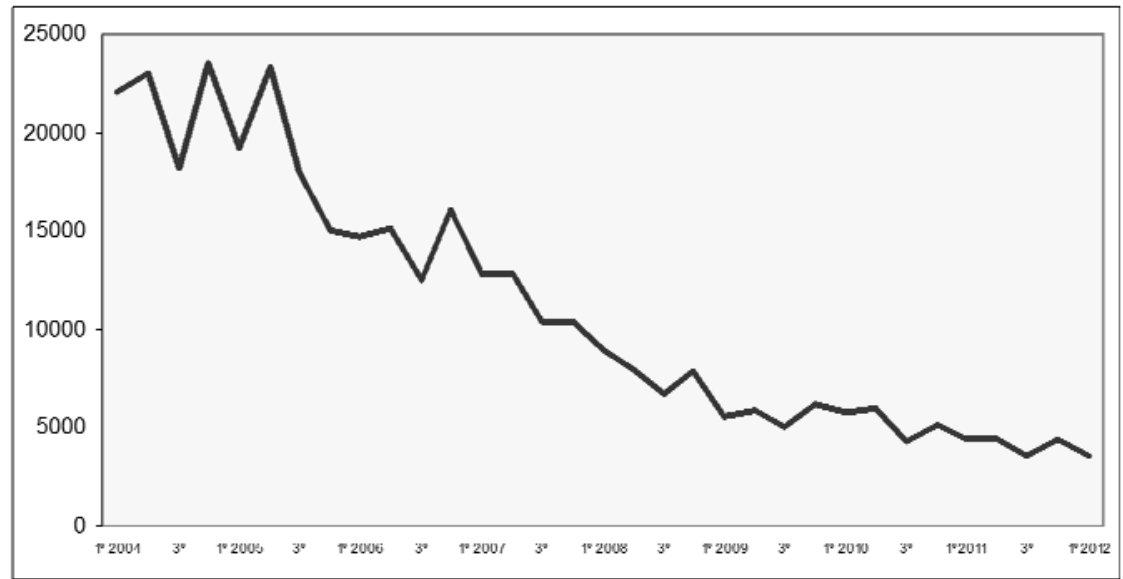

\section{Gráfico 11. Tasas interanuales de las transac ciones de suelo Graph 11. Year-on-year rates of soil transactions}

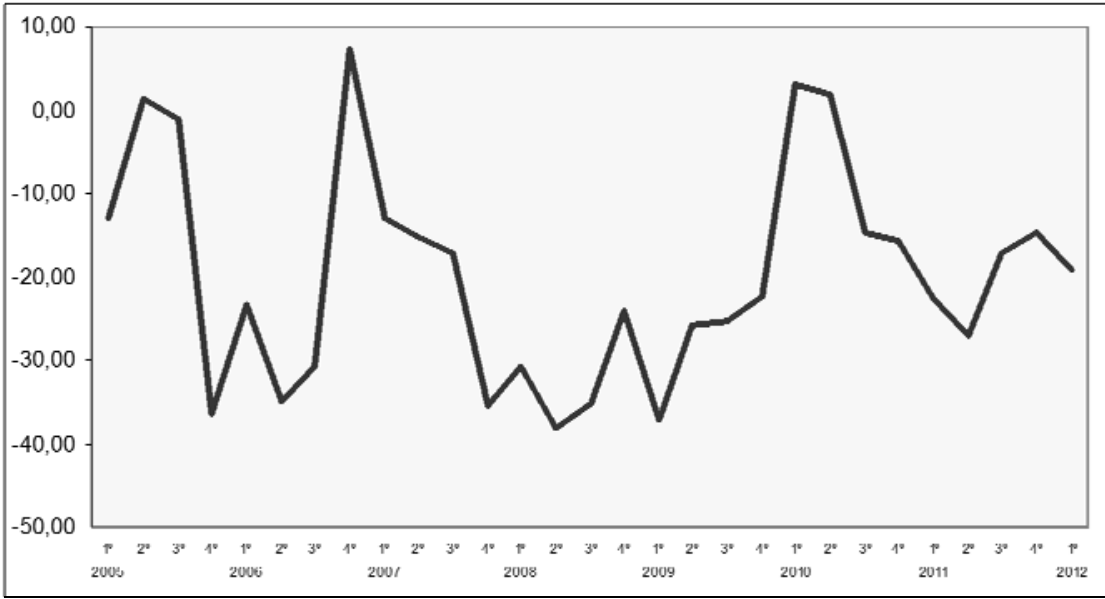

Se puede deducir que el número de transacciones realizadas en el primer trimestre de 2012 fue de 3.598, un $18,6 \%$ menos que las realizadas en el cuarto trimestre de 2011, que fue de 4.420 , y un $19,2 \%$ menos que las que se realizaron en el primer trimestre de 2011 , donde se transmitieron 4.453 solares.
It can be inferred that the number of transactions developed in the first quarter of 2012 was 3,598, which means an $18.6 \%$ lower than the number in the last quarter of 2011, when it was 4,420, and a $19.2 \%$ lower than the number of transactions developed in the first quarter, when 4,453 pieces of land were transferred. 
En el Gráfico 10 se aprecia claramente un descenso de la tendencia del número de transacciones.

En el siguiente Gráfico se observa la evolución de las tasas interanuales del precio del suelo y el de la vivienda de obra nueva:
In Graph 10 it is clearly observed that the trend in the number of transactions has decreased.

The graph below shows the evolution in the year-on-year rates for soil and new housing prices.

\section{Gráfico 12. Tasas interanuales de precios de vivienda y de precios de suelo / Graph 12. Year-on-year rates of housing and soil prices}

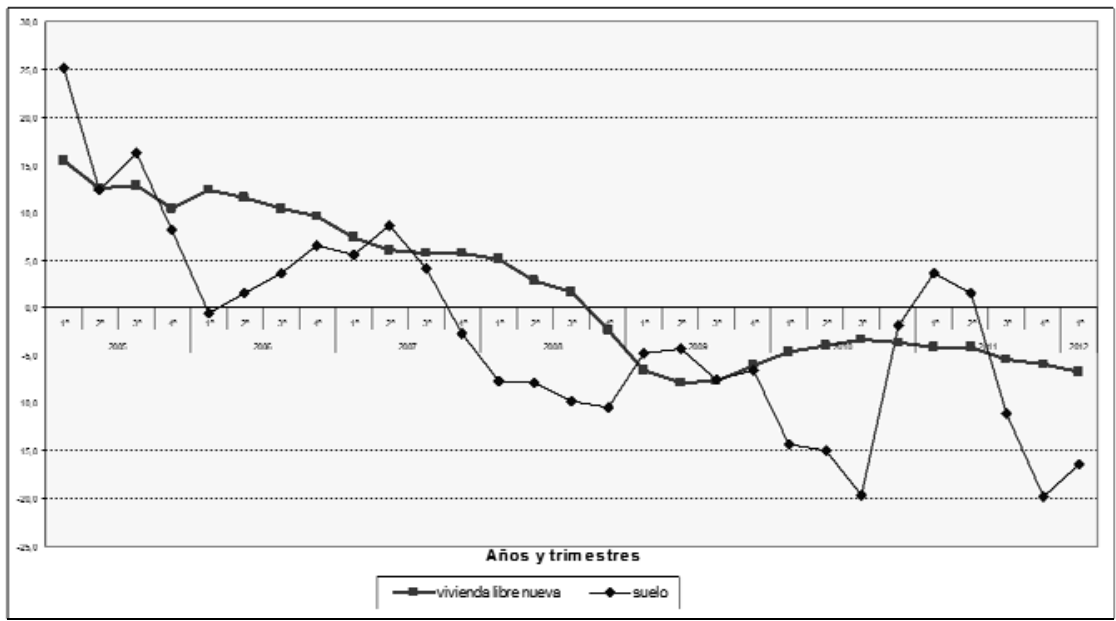

\section{CONCLUSIONES}

El objetivo del análisis que hemos llevado a cabo ha sido comprobar la evolución de la que han sido objeto tanto el sector de la vivienda como el sector del suelo, en los últimos años, a partir de la información que se obtiene de las estadísticas de precios de vivienda y de precios de suelo, elaboradas por la Subdirección de Estudios Económicos y Estadísticas del Ministerio de Fomento.

Dicha información, nos ha permitido corroborar que el ajuste, tanto del sector de la vivienda como del sector del suelo, se inicia a finales de 2007 y principios de 2008.

\section{CONCLUSIONS}

The aim of this study has been to analyse the evolution in both the housing and soil sectors in recent years, by using the information available in the statistics of housing and soil prices, which are prepared by the Subdirección de Estudios Económicos y Estadísticas belonging to the Ministerio de Fomento.

That information has allowed us to confirm that the adjustment in both the housing and soil sectors started at the end of 2007 and the beginning of 2008. 
Desde el año 2004 hasta principios de 2008 los precios de vivienda libre son objeto de subida, mientras que a partir de esta última fecha se comprueba que los precios empiezan a bajar. En cuanto a los precios de suelo, es a finales de 2007 cuando se aprecia un descenso de la tendencia.

Asimismo, de los datos analizados en el trabajo se desprende que a partir de finales de 2006 se produce un descenso de la tendencia en el número total de transacciones inmobiliarias, lo que también se observa en lo que se refiere al número de transacciones de suelo, en las que hay un claro descenso de la tendencia a partir de finales de 2006.
From 2004 to the beginning of 2008, free-market housing prices increased, whereas from 2008 prices have started to fall. Regarding soil prices, it is the end of 2007 the one which shows a decrease in their trend.

Furthermore, from the analysed data in this paper it is deduced that from the end of 2006 onwards the trend of the total number of real estate transactions has decreased, which is also observed regarding the number of soil transactions, in which there is a clear fall in their trend starting from the end of 2006.

\section{BIBLIOGRAFÍA/REFERENCES}

BBVA (2010). Situación España. Servicio de Estudios Económicos, segundo trimestre.

Bueno Miralles, B. (2009). El poliedro de la vivienda. Estudio de la vivienda protegida de acuerdo con el Plan Estatal 2009-2012. Madrid: La Ley.

Carbajo Nogal, C. (2010). La Fiscalidad de la vivienda en España: análisis de sus efectos jurídicos y económicos (Tesis Doctoral). Universidad de Burgos.

García Delgado, J.L. y Jiménez, J.C. (1999). Un siglo de España. La economía. Madrid: Marcial Pons.

García Montalvo, J. y Mas, M. (2000). La vivienda y el sector de la construcción en España. Valencia: Caja de Ahorros del Mediterráneo.

Juárez, M. (Dir.) (1994). Vivienda. V Informe sociológico sobre la situación de la vivienda en España. Sociedad para todos en el año 2000 (Vol. II, Cap. 10). Fundación Focea (Fomento de Estudios Sociales y de Sociología Aplicada).

Ministerio de Fomento (2000). Atlas estadístico de las áreas urbanas en España. Serie Monografías.

Ministerio de Vivienda (2006). Estudio sobre el mercado de la vivienda en España. Previsiones 2007-2009.

Ministerio de Vivienda (2006). Estudio sobre la situación y perspectivas futuras en el sector inmobiliario en España.

Ministerio de Vivienda (2009). Estudio sobre el stock de viviendas a 31 de enero de 2008. 
Ministerio de Vivienda (2010). Estadística de precios de suelo.

Ministerio de Vivienda (2010). Estadística de precios de vivienda.

Ministerio de Vivienda (2010). Estadística de transacciones inmobiliarias.

Ponce Solé, J. y Sibina Tomás, D. (Coord.), (2008). El derecho de la vivienda en el siglo XXI: SuS relaciones con la ordenación del territorio y el urbanismo. Con un análisis específico de la Ley catalana 18/2007, de 28 de diciembre, del derecho a la vivienda, en su contexto español, europeo e internacional. Madrid: Marcial Pons.

Rodríguez Alonso, R. (2005). La política de vivienda en España desde la perspectiva de otros modelos europeos. Boletín CF+S, 29/30. http://habitat.aq.upm.es/boletin/n29/arrod2.html.

Servicio de Estudios Económicos del BBVA. Situación Inmobiliaria. Diciembre 2008. http://www.bbvaresearch.com/KETD/fbin/mult/ESIES_0812_Situacioninmobiliaria_24_tcm346183823.pdf?ts=2012014.

Tinaut Elorza, J.J. (2006). Desarrollos recientes de la política estatal de vivienda en España: el Plan 2005-2008. Papeles de Economía Española, 109, 273-290. 